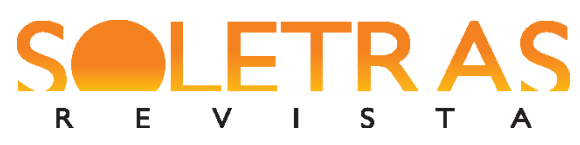

N. 36 - 2018.2 - EMILE CARDOSO ANDRADE

EWERTON DE FREITAS IGNÁCIO

\title{
Uma literatura do desassossego: interculturalidades e política em Neve de Orhan Pamuk
}

\author{
Emile Cardoso Andrade ${ }^{1}$ \\ Ewerton de Freitas Ignácio ${ }^{2}$
}

Resumo: A literatura do século XXI pode ser definida como uma produção que se preocupa com a experiência intercultural do sujeito em tempos globalizados e de convergência midiática. Nesse sentido, os escritores de agora buscam - a partir do mal-estar oriundo do entre-lugar pelo qual os sujeitos contemporâneos transitam - aproximar-se de discussões orientadas para o sentido do que ainda pode ser pensado sobre a política e os aspectos interculturais que permeiam nosso mundo. Sob este viés, interessa-nos investigar a construção narrativa de Neve, romance de Orhan Pamuk, publicado no Brasil em 2006, tecendo relações entre as noções de ficção e realidade, e como estas instâncias são mediadas pela televisão e pelo teatro e concorrem para problematizações interculturais, políticas e religiosas dos tempos atuais.

Palavras-chave: Interculturalidade. Política. Neve. Orhan Pamuk.

Julgamos possível postular que uma parte da produção literária do final do século XX e início do século XXI - tanto no Ocidente quanto no Oriente - é tributária do que podemos denominar "drama intercultural", haja vista que muitas das obras publicadas nessa virada de século são plasmadas por uma preocupação que incide sobre o problema étnico, o choque entre culturas e identidades, os evidentes deslocamentos e os entre-lugares, os quais se constituem cenários propícios para a irrupção das múltiplas e variadas vozes que formam o corpo literário do que se produz até os dias de hoje.

Essa assertiva, embora em um primeiro momento possa parecer forçosamente generalista, pode ser corroborada se levarmos em conta uma leva de autores contemporâneos cuja preocupação se estende pelas relações entre muitas culturas. $\mathrm{O}$ americano Philip Roth, falecido a pouco, é um exemplo desse fenômeno. Além de narrar a experiência judaica nos Estados Unidos desde a Primeira Guerra Mundial até os dias atuais (Complô contra a América, 2004 e Nêmesis,

\footnotetext{
${ }^{1}$ Doutora em Literatura pela Universidade de Brasília (UnB), docente do Programa de Pós-graduação Stricto Sensu em Língua, Literatura e Interculturalidade (POSLLI) na Universidade Estadual de Goiás (UEG), Goiás, GO, Brasil. E-mail: emilecardoso@yahoo.com.br.

${ }^{2}$ Doutor em Literaturas em Língua Portuguesa com estágio pós-doutoral em Literatura Brasileira pela Universidade Estadual Paulista (UNESP). Professor do curso de Letras e do Programa de Pós-graduação Stricto Sensu em Territórios e Expressões Culturais do Cerrado (TECCER/UEG), Goiás, GO, Brasil. E-mail: ewertondefreitas@uol.com.br.
} 


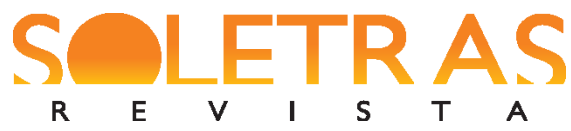

N. 36 - 2018.2 - EMILE CARDOSO ANDRADE

EWERTON DE FREITAS IGNÁCIO

2010), o premiado romancista dá corpo e espírito à complexa relação dos imigrantes cubanos na América contemporânea em $O$ animal agonizante (2001). Por sua vez, o ganhador do Nobel de 2017, Kazuo Ishiguro, foi escolhido pela academia sueca por revelar uma força emocional em seus romances cuja natureza é oriunda das intrincadas relações entre a cultura inglesa e o Japão, além das complexidades políticas vivenciadas, por exemplo, pela sangrenta guerra entre japoneses e a China, contexto do romance Quando éramos órfãos, publicado pela primeira vez em 2000. Enfim, para não deixar de citar um caso brasileiro, encontramos na prosa de Bernardo Carvalho aspectos interculturais que refletem o caminho da literatura no início do século XXI: em seu romance $O$ filho da mãe (2009), um narrador polifônico atravessa tempos e espaços diversos (Oiapoque, Japão, Rússia) a fim de aproximar-se do sofrimento das mães daqueles que vivenciam a guerra. Essas obras, apenas para citarmos algumas, colocam a questão do que denominamos de "drama intercultural" na pauta de discussões, visto que problematizam questões como os deslocamentos, as ambivalências da experiência de fronteira e os desencontros oriundos da multiplicidade de línguas, histórias, religiões, costumes e comportamentos.

As narrativas interculturais produzidas nesse contexto também poderiam se chamar como propôs o escritor italiano Antônio Tabucchi (2002, p. 14) - de literatura do desassossego. ${ }^{3}$ O desconsolo ao qual nos remete tal denominação justifica-se na medida em que se observa, a partir dos anos 1990, um frequente interesse do artista literário em se fixar no sujeito contemporâneo e seus tormentos, seus deslocamentos por e em um mundo cada vez mais global e, justamente por isso, mais fragmentado.

Outros nomes de escritores que sirvam como exemplos dessa literatura intercultural não faltam: V. S. Naipaul, J.M. Coetzee, Chimamanda Adichie e Milton Hatoum estão entre os autores que se preocupam com essa discussão cada vez mais frequente na produção literária. A inquietação do sujeito contemporâneo, em trânsitos culturais cada vez mais intensos, é uma continuada experiência que transborda a perspectiva real e surge como força estética nas artes do século XXI.

\footnotetext{
${ }^{3}$ Tabucchi utiliza o termo desassossego retomando o mais contemporâneo dos pseudônimos de Fernando Pessoa, Bernardo Soares, cujas reflexões tecidas no Livro do Desassossego prenunciam diversas preocupações e discussões contemporâneas.
}

SOLETRAS - Revista do Programa de Pós-Graduação em Letras e Linguística - PPLIN

Faculdade de Formação de Professores da UERJ

Número 36 (jul.-dez. 2018) - ISSN: 2316-8838

DOI: https://doi.org/10.12957/soletras.2018.33698 


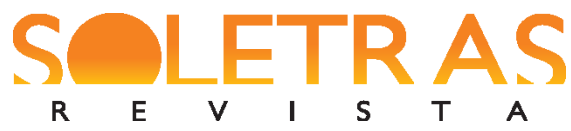

N. 36 - 2018.2 - EMILE CARDOSO ANDRADE

EWERTON DE FREITAS IGNÁCIO

Orhan Pamuk também está entre esses autores. O escritor turco é considerado um dos intelectuais mais representativos dessa geração de artistas literários que fizeram da inquietude e do estranhamento, das diferenças e das incomunicabilidades, os principais motes de suas obras. $\mathrm{O}$ romance Neve, publicado no Brasil em 2006, mesmo ano em que Pamuk foi agraciado com o Prêmio Nobel de Literatura, discorre sobre a dupla identidade da Turquia e os choques culturais entre Ocidente e Oriente, que se configuram como característica marcante do país natal de Pamuk.

Essa reflexão acerca das divisões da sociedade turca entre Ocidente e Oriente, tecida no contexto narrativo de Neve, é o que justamente culminou na escolha de Pamuk como ganhador do maior prêmio da literatura universal. Segundo nota do júri da Academia sueca, o romancista turco é um escritor que encontrou novas maneiras de pensar as ambiguidades culturais da Turquia e do mundo contemporâneo ao buscar a essência melancólica de sua cidade.

Possivelmente, um desses novos símbolos encontrados pelo escritor seja a singular relativização dos aspectos culturais e identitários reveladores de uma Turquia dividida entre leste e oeste, uma relativização que, problematizada no contexto narrativo do romance, configura-se como resultando de uma apurada percepção, por parte do romancista, desse entrecruzamento de culturas e identidades de um povo.

O romance Neve, como procuraremos evidenciar, não se furta a esse debate de viés cultural; procura, ao contrário, trazê-lo para o centro de sua trama, discutindo-o - e ressignificando-o - no interior de sua arquitetura romanesca. Desse modo, por meio de uma intrincada rede de acontecimentos cujo cenário é uma pequena cidade turca insulada pela neve, Pamuk constrói uma narrativa centrada no personagem Ka, um poeta turco que acabara de sair de um longo (e improdutivo, do ponto de vista poético) exílio na Alemanha. Seu intuito, ao visitar a cidade de Kars, é fazer uma cobertura jornalística de uma série de suicídios entre moças que supostamente se viram obrigadas a retirar seus véus em público. Considerado um estrangeiro, Ka é um "outsider", sendo visto com desconfiança pela maioria dos habitantes de Kars. Sua situação torna-se ainda mais complicada quando se vê envolvido em um golpe de Estado que o transporta a um entre-lugar complexo e singular: o protagonista se vê na brecha entre a defesa 


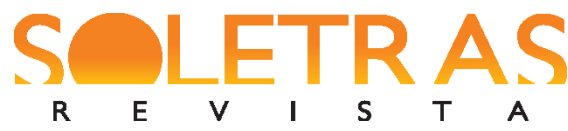

N. 36 - 2018.2 - EMILE CARDOSO ANDRADE

EWERTON DE FREITAS IGNÁCIO

fundamentalista do Islã e o estabelecimento de um regime radical que defende os valores laicos impostos por Kemal Antatürk (fundador do Estado turco moderno).

O propósito de nossas observações centra-se na discussão acerca das construções narrativas nesse romance de Pamuk e a convergência entre questões interculturais, políticas e religiosas que permeiam o universo literário desse primeiro quartel do século XXI. Interessa-nos investigar como se configuram as noções de real, ficção e farsa dentro do contexto narrativo do romance e de que maneira esses conceitos se conectam e dão ao texto de Neve o seu propósito reflexivo. Importa-nos também verificar de que forma a realidade é mediada e construída pelo espetáculo teatral e televisivo (elementos fundamentais no romance em tela) e como podemos conceber e entender a realidade ficcional de Pamuk e sua obra em tempos de reprodutibilidade técnica (BENJAMIN, 1994).

Pamuk e seu personagem - o poeta Ka - viveram a experiência do deslocamento, uma vez que estiveram, cada um a seu modo, na condição de exilados. Pamuk fez uma estadia nos Estados Unidos depois de suas polêmicas considerações sobre o massacre de armênios e os embates com a guerrilha curda em seu país. Já o poeta de Neve esteve exilado na Alemanha por muitos anos, o que para ele se constituiu em uma experiência traumática que, por seu turno, resulta em um travamento criativo, em razão do qual a personagem não conseguiu produzir sequer um poema no período compreendido por seu exílio. De volta à Turquia, ele se estabelece temporariamente em Kars, interessado que estava em saber de pormenores relativos à onda de suicídios de mulheres da cidade; porém, continua sendo considerado um estrangeiro, só que, dessa vez, em sua própria terra natal. Essa posição "outsider" à qual se refere Edward Said é uma marca da literatura produzida nos fins do século XX, início do XXI; é uma posição fundamentalmente desprovida de territorialidade e, por isso, uma experiência indizível de solidão e silêncio:

Na escala do século XX, o exílio não é compreensível nem do ponto de vista estético, nem do ponto de vista humanista: na melhor das hipóteses, a literatura sobre o exílio objetiva uma angústia e uma condição que a maioria das pessoas raramente experimenta em primeira mão (SAID, 2003, p. 48). 


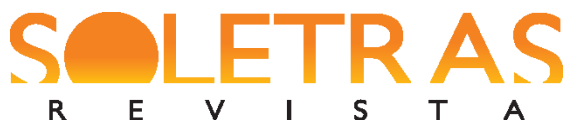

N. 36 - 2018.2 - EMILE CARDOSO ANDRADE

EWERTON DE FREITAS IGNÁCIO

Neste contexto de barbárie, os escritores que se projetam são destituídos de um espaço de experiência sensível e - em maior ou menor medida - também não se fixam em termos linguísticos. A suspensão da geografia particular leva o sujeito contemporâneo à vivência de uma incerteza cuja tradução estética é o isolamento íntimo pela qual passa a maioria dos personagens de Neve.

Esta é a posição de Ka: a de um estrangeiro em seu próprio país, a de um poeta sem casa, que não se fixa em nenhuma territorialidade e nem sequer assume, como sua, uma identidade que não seja fluida ou provisória. Assim como seu país de origem, Ka é uma mistura de várias culturas, e o leste e o oeste estão presentes tanto nele quanto na Turquia de uma forma ambivalente, uma vez que, se em alguns momentos parecem caminhar juntos, em outros instantes se desarticulam, acabando por se desagregarem por completo.

Nesse liame, torna-se necessário um curto esclarecimento sobre a dupla posição da Turquia nos fins do século XX e como essa singularidade se expande para questões adjacentes. Sua posição geopolítica configura-se de maneira única no mapa-múndi. Como consequência da $1^{\text {a }}$ Guerra Mundial, a queda do Império Otomano (1299-1922) deu origem à Nova República da Turquia que se conhece hoje, laicizada em 1923 por Kemal Atatürk, seu primeiro presidente.

Istambul (antiga Constantinopla) sempre foi vista como porta de entrada da Europa para a Ásia. À capital turca pertence o Estreito de Bósforo, cuja ponte faz a conexão entre a Europa e a Ásia, sendo a única cidade do planeta que se estende por dois continentes. Durante a Guerra Fria, em virtude dessa posição geográfica estratégica, a Turquia serviu de elo terrestre entre Leste e Oeste, uma vez que Kemal defende uma posição neutra nos conflitos internacionais. As reformas por ele empreendidas transformaram a Turquia num país secular e democrático, mas, ao mesmo tempo ambíguo, por sua tradição e seu histórico islâmico. Essa ambivalência gerou conflitos entre aqueles interessados nas mudanças instituídas por Kemal e os conservadores, que não viam com bons olhos essa "ocidentalização". Enfim, a posição intermediária dos turcos é de ordem geográfica, histórica, política, religiosa e cultural, permanecendo assim até os tempos atuais, como encontramos no romance de Pamuk.

Dessa desagregação entre a cultura do leste e do oeste turcos, à qual corresponde uma desarticulação interna do próprio narrador-protagonista, que se vê dividido e habitante de um

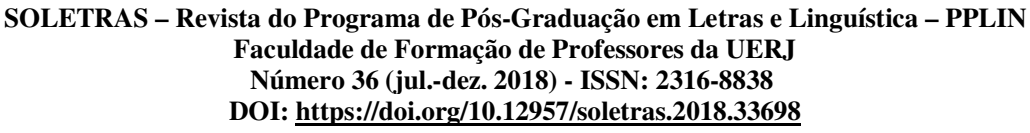




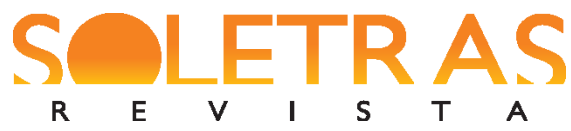

N. 36 - 2018.2 - EMILE CARDOSO ANDRADE

EWERTON DE FREITAS IGNÁCIO

espaço tensionado por forças divisórias, decorre uma ambiguidade espacial e identitária do referido narrador, que coloca em ação a ideia de um entre-lugar cuja experiência perfaz todo o romance, porque "estar entre as coisas entre-lugares diz respeito a não ser isso nem aquilo, um ou outro, mas à chance de um vir-a-ser outro possibilitado justamente por essa indefinição" (GUATELLI, 2012, p.14).

Observe-se que, no contexto narrativo de Neve, além de se ter a representação da vivência de um narrador-protagonista em seu segundo exílio - dessa vez dentro dos limites geográficos de sua própria pátria -, o que faz com que a subjetividade dessa personagem se configure como desagregada, a própria realidade apresentada por Pamuk nos parece igualmente desagregada, de modo a plasmar uma fragmentação que percorre dois sentidos principais que, por sua vez, se entrelaçam ao longo da trama: o sentido político e o sentido estético. A discussão política em torno da difícil relação entre o radicalismo islã e a defesa de uma Turquia secular mistura-se às atividades poéticas de Ka e o problema da representação artística no teatro e na televisão, de modo que se tem, no enredo do romance, o entrecruzamento temático de política, religião e aspectos culturais. As observações que se seguem tentam esclarecer como essas questões estão expostas em Neve.

Ka encontra-se numa encruzilhada política ao envolver-se (embora sem quaisquer convicções sólidas) com dois lados antagônicos do poder na cidade: em um primeiro momento ele mantém contato com Azul - um radical islamita perseguido pelo regime que se estabelece por meio do golpe - e, em um segundo momento, é uma das personagens centrais do espetáculo teatral que se transforma no golpe de Estado promovido pelos defensores de uma Turquia laica e ocidentalizada, segundo os moldes de Atatürk. Ao mesmo tempo em que essa trama se desenrola, Ka entra num período de extrema produtividade poética e seus poemas passam a ser a única atividade à qual ele se dedica com afinco, além de um envolvimento amoroso com Ipek, uma antiga colega de faculdade.

Quanto a Azul, é possível afirmar que tal personagem não se configura como um radical islamita descrito pelo que poderia imaginar o senso comum: trata-se, antes, de um homem bonito, sedutor, bem trajado e muito asseado, que possui penetrantes olhos azuis e que ficara conhecido 


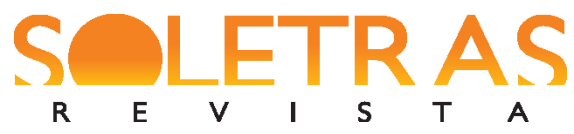

N. 36 - 2018.2 - EMILE CARDOSO ANDRADE

EWERTON DE FREITAS IGNÁCIO

por ser acusado de ser o responsável pela morte de um apresentador de programa de televisão.

Por isso vivia às escondidas e era procurado:

A notoriedade de Azul se devia ao fato de ter sido responsabilizado pela morte de uma personalidade do mundo televisivo, o efeminado e exibicionista Güner Bener, em cujo programa de perguntas e respostas, transmitido por uma pequena emissora, os candidatos disputavam prêmios em dinheiro (PAMUK, 2006, p. 87).

Azul, além de ser descrito como um galã, só consegue reconhecimento na condição de terrorista islã quando se envolve diretamente na morte de uma celebridade da televisão. Aqui temos a primeira referência importante, no contexto narrativo do romance, ao mundo da mídia televisiva, presença que marcará definitivamente a trama e passará a conter um significado bastante expressivo, na medida em que articula - entre os espaços reais e ficcionais - os conflitos de natureza política, social e cultural permeados na obra.

Novamente, encontramos as personagens enredadas em filigranas que, em seu conjunto, plasmam um entre-lugar cujas características e feição acabam por ultrapassar o sentido estrito de localidade física, expandindo-se e irradiando-se para as franjas do que se constitui como vivências políticas, religiosas e estéticas:

O espaço intermediário seria compreendido aqui como uma indefinição, um espaço aberto às significações entre espaços definidos, espaços estes que seriam os agentes catalisadores, motivadores dessas reações dos usuários, desses eventos, desses acontecimentos inesperados que surgiriam e permaneceriam sempre em processo, transitórios (GUATELLI, 2012, p. 33).

Do outro lado do embate político de Kars, está a figura do ator Sunay, artista que percorria as cidades turcas fazendo apresentações teatrais e que, por ter certa semelhança com o estadista Kemal Atatürk, foi indicado para interpretá-lo no cinema: "As platéias turcas não tinham dúvida de que Sunay, com toda a sua elegância, nobreza de porte e capacidade de inspirar confiança, daria um excelente Atatürk" (PAMUK, 2006, p. 223). Sunay foi o homem responsável

SOLETRAS - Revista do Programa de Pós-Graduação em Letras e Linguística - PPLIN

Faculdade de Formação de Professores da UERJ

Número 36 (jul.-dez. 2018) - ISSN: 2316-8838

DOI: https://doi.org/10.12957/soletras.2018.33698 


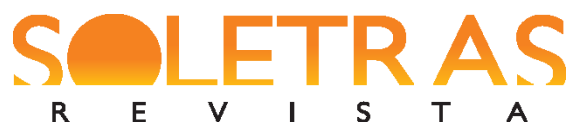

N. 36 - 2018.2 - EMILE CARDOSO ANDRADE

EWERTON DE FREITAS IGNÁCIO

pelo golpe militar cuja realização ocorreu em meio a um espetáculo de teatro programado e encenado por ele, sua mulher e seus aliados políticos.

O espetáculo teatral promovido por Sunay e televisionado para toda Kars é o ponto central do romance. Várias são as atrações apresentadas, inclusive a leitura do poema de Ka; o momento mais importante desse espetáculo, todavia, fica por conta da representação da peça "Minha pátria ou meu manto", em cujo intercurso, de modo inesperado, soldados surgem do palco e atiram impiedosamente na plateia:

Antes que o público tivesse tempo de assimilar a notícia, os soldados que estavam no palco engatilharam seus rifles, apontaram diretamente para a platéia e abriram fogo imediatamente; o barulho foi ensurdecedor.

Não estava claro se aquilo era um artifício dramático ou uma guarda de honra solicitada pela companhia para dar maior relevo à notícia. Muitos moradores de Kars - que nada sabiam das modernas convenções teatrais - pensaram tratar-se de mais um lance de teatro experimental (PAMUK, 2006, p. 183).

O público do teatro - bem como os telespectadores, que ficaram em casa assistindo à apresentação pela TV -, demoraram, em razão do inusitado da situação, um tempo considerável para se darem conta de que estavam presenciando e sendo vitimados por uma verdadeira chacina, perpetrada com frieza e crueldade, e não de que assistiam à representação de um ato de teatro vanguardista:

Só na terceira saraivada algumas pessoas da platéia se deram conta de que os soldados estavam atirando de verdade; dava para saber, da mesma forma que se sabia nas noites em que soldados caçavam terroristas nas ruas, porque os tiros eram percebidos tanto pelos ouvidos como pelo abdômen. (PAMUK, 2006, p. 184).

Entre o real e o ficcional, entre o fato político e a ilusão teatral, os habitantes de Kars surpreenderam-se com a maneira singular com que o grupo kemalista toma o poder e instaura na cidade um regime que se deixa regular sob a égide da truculência e do terror. Nesse aspecto, notase que a representação artística toma vida e invade a realidade dos moradores da cidade em um extraordinário espetáculo assistido por todos, fazendo com quem as palavras de Debord sejam

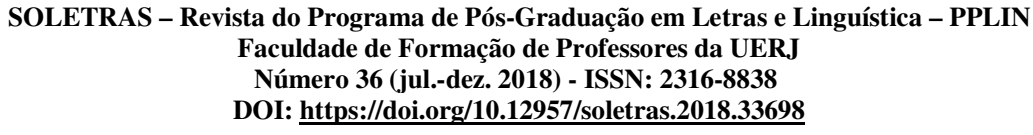




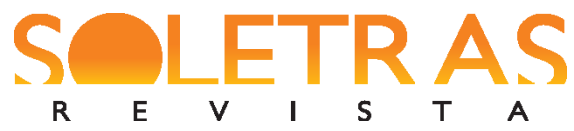

N. 36 - 2018.2 - EMILE CARDOSO ANDRADE

EWERTON DE FREITAS IGNÁCIO

lembradas: "Toda a vida das sociedades nas quais reinam as modernas condições de produção se apresenta como uma imensa acumulação de espetáculos. Tudo o que era vivido diretamente tornou-se uma representação" (DEBORD, 1997, p. 13). O acontecimento político de maior proporção em Kars é realizado sob uma forma de espetáculo, ou seja, a representação precede a realidade e consequentemente a transforma em representação numa espécie de círculo vicioso em que as duas instâncias não mais se distinguem.

Outro fato relevante refere-se à distribuição midiática do espetáculo teatral. Para que a representação do golpe político se realizasse por completo, fazia-se absolutamente necessário que não só o público presente no teatro, mas também todos os moradores de Kars, assistissem ao espetáculo. Para o cumprimento dessa premente necessidade, nada mais eficaz do que a televisão para reproduzir a imagem do que se passava no palco.

O sentido da arte contemporânea passa pela capacidade que essa arte possui de se distribuir e se reproduzir para atingir seu público. A esse respeito, Walter Benjamin assegura que "a arte contemporânea será tanto mais eficaz quanto mais se orientar em função da reprodutibilidade e, portanto, quanto menos colocar em seu centro a obra original" (Benjamin, 1994, p. 180). Não importa, portanto, que a cena teatral tenha ocorrido, mas sim que ela possa ser reproduzida e reapresentada. É o que ocorre aos moradores de Kars que, por terem a oportunidade de rever as cenas no teatro, tentam - a partir dessa reapresentação dada pela televisão - entender o acontecimento:

Sentada diante de seus televisores, esforçando-se para entender o que estava acontecendo, a maioria começou a temer o pior. Os que estavam muito cansados ou meio bêbados se pegaram rememorando os velhos tempos de perturbação da ordem pública; outros temiam a volta das mortes, desaparecimentos, e o império das trevas. Os que não se interessavam por política viram na reapresentação do programa uma oportunidade de tentar entender o que aconteceu naquela noite da mesma forma que eu próprio faria, muitos anos depois - e por isso voltaram a se concentrar na televisão (PAMUK, 2006, p. 199).

Cumpre observar que é justamente em razão dessa impossibilidade de reprodução técnica que o teatro é visto, por Walter Benjamin, como a forma de arte mais distante daquelas 


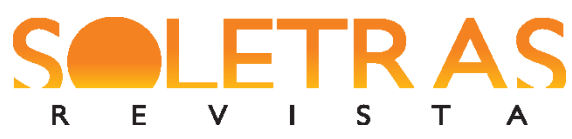

N. 36 - 2018.2 - EMILE CARDOSO ANDRADE

EWERTON DE FREITAS IGNÁCIO

construídas a partir das revoluções dos aparelhos óticos e dos instrumentos de cópia, tão caros às artes contemporâneas:

(...) a arte dramática é de todas a que enfrenta a crise mais manifesta. Pois nada contrasta mais radicalmente com a obra de arte sujeita à reprodução técnica, e por ele engendrada, a exemplo do cinema, que a obra teatral, caracterizada pela atuação sempre nova e originária do ator (BENJAMIN, 1994, p. 180-1).

E aí temos, novamente, a presença da televisão como um elemento fundamental na construção da trama de Neve: ela funciona como difusora de imagens e como reconfiguradora de novas realidades, não se limitando a reproduzir o real, mas alçando-se à condição de propiciadora de uma realidade reconfigurada pelo poder televisivo. Nesse sentido, a mídia televisiva toma conta do real e, no intuito de descrevê-lo, exagera em seu propósito, acabando por se tornar a própria realidade. Note-se que, a esse respeito, Baudrillard assevera o seguinte:

A televisão chama bastante a atenção nos tempos que correm. Faz falar dela. Em princípio, ela está aí para nos falar do mundo e para apagar-se diante do acontecimento como um médium que se respeite. Mas depois de algum tempo, parece, ela não se respeita mais e toma-se pelo acontecimento (BAUDRILLARD, 2005, p. 141).

Em Kars (ou seja, no universo ficcional de Neve), a notícia precede o acontecimento. O dono do jornal da cidade, Serdar bei, possui a notória qualidade de escrever manchetes que ainda não aconteceram e publicá-las na certeza de que serão realidade no momento em que forem vendidas. Foi assim quando Ka leu seu poema no espetáculo que resultou no golpe de Estado e foi assim também quando Sunay quis antecipar sua morte, escrevendo ao jornal a manchete de seu assassinato: "Sedar bei prometeu publicar o artigo que eles queriam; eles podiam ditar cada detalhe, e até indicar as dimensões da manchete. (...) Ele lembrou a todos que, durante quase toda a sua carreira, escrevera sobre eventos ainda por acontecer: podia-se dizer que aquele era o seu forte " (PAMUK, 2006, p. 382). 


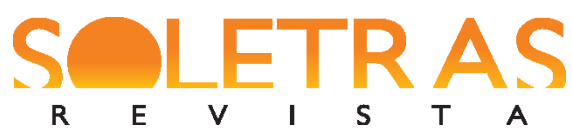

N. 36 - 2018.2 - EMILE CARDOSO ANDRADE

EWERTON DE FREITAS IGNÁCIO

O poder da mídia faz-se maior do que a própria realidade. Isso significa que o simulacro não apenas representa, mas toma o lugar do real. Retomando uma fábula de Borges em que cartógrafos desenham o mapa de um Império tão detalhadamente que acabam por encobrir todo o seu território, Baudrillard nos fornece uma perfeita analogia deste fenômeno que ele mesmo denomina "a precessão dos simulacros": "O território já não precede o mapa, nem lhe sobrevive. É agora o mapa que precede o território - precessão dos simulacros - é ele quem engendra o território cujos fragmentos apodrecem lentamente sobre a extensão do mapa" (BAUDRILLARD, 1991, p. 8).

O momento crucial do romance instala-se sobre o golpe de Estado perpetrado por Sunay, e a forma como este golpe foi articulado. Dessa maneira, é possível afirmar que há um processo de reflexividade entre a atividade política programada pelos golpistas e o espetáculo teatral engendrado para tanto - articulação que se torna potencializada pela transmissão de tevê. Há portanto uma relação de espelhamentos entre as várias camadas de representação narradas na obra. Diante disso, remontamos os esclarecimentos de Luiz Costa Lima acerca da noção e desenvolvimento do conceito de mímesis e sua problematização no universo ficcional:

No cotidiano, a ficção é sinônimo de embuste, fabricação, falsidade, fantasia, fingimento ou decorrente da crença em algo que tomamos como verdadeiro. É só na experiência literária que ela encontra o desideratum necessário ao processo da mímesis. Processo que então não se confunde com o da experiência do eu, mas, ao contrário, com a vivência de seu desdobramento (LIMA, 2007, p. 81).

Ao negar a sinonímia entre mímesis e imitativo, Luiz Costa Lima amplifica e explora com mais desenvoltura a noção de representação artística, e nos coloca diante da ideia de desdobramento, ou seja, da possibilidade de uma obra abrir-se em inúmeras representações. No caso do romance em questão, a narrativa do golpe espelha-se na peça de teatro, que, por sua vez, expande-se na emissão televisiva; ou seja, o evento fulcral da trama se desvela como uma matrioska, a tradicional boneca russa feita de várias figuras umas dentro das outras. $\mathrm{O}$ universo contemporâneo de convergência entre mídias permite esse ato reflexivo, que reverbera num modo singular de efeito estético; ou, neste caso, um efeito também político. 


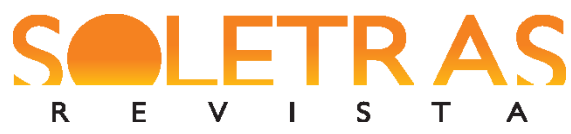

A sociedade motivada pelo espetáculo da mídia assiste a tudo imóvel e aceita deliberadamente o jogo de troca de lugares entre realidade e representação. Em Kars, os tanques militares já percorriam as ruas a declarar tacitamente que se iniciara tempos de terror; porém, a sociedade que assistia a tudo pelos televisores não encontrava motivo para aflição. O golpe mostrado pela TV parece mais distante, e, portanto, menos real, fazendo da imagem dos tanques na rua também uma ficção, que o narrador descreve como "um velho conto de fadas":

A essa altura todos em Kars já se tinham dado conta de que estava havendo um golpe - se não se tratasse de um golpe, bastava olhar os dois tanques que vagavam pela cidade como pesados fantasmas sombrios para ter certeza de que alguma coisa muito estranha estava acontecendo -, mas como também estavam assistindo ao espetáculo em suas telas de televisão e como a neve continuava a cair interminavelmente (suas janelas pareciam o cenário de um velho conto de fadas), os tanques não inspiravam nenhum medo. Os únicos que se mostravam ansiosos eram os ativistas políticos (PAMUK, 2006, p. 200).

A força da imagem televisiva também fica evidente quando o narrador-protagonista confere certa importância à novela acompanhada por todos na cidade. Não há qualquer outro motivo que justifique o fato de a novela Marianna ser alvo de descrição e preocupação do narrador. A proposição de que este espetáculo melodramático esteja inserido na trama do romance existe simplesmente por conta da extrema relevância da televisão como mídia reprodutora ideal ao contexto político de Kars:

\footnotetext{
Marianna era uma novela mexicana transmitida cinco vezes por semana por um dos grandes canais de televisão de Istambul, para grande satisfação de todo país. A heroína, que emprestava o nome à série, era uma garota pequena, esfuziante e encantadora, de grandes olhos verdes e pele clara o bastante para sugerir uma origem abastada. Não obstante ela provinha de uma classe bem humilde. A inocente Marianna, de longos cabelos, ficara órfã ainda muito criança e passara a maior parte da vida pobre e solitária (raramente se passava um dia sem um novo revés) e, sempre que ela se apaixonava por alguém que não correspondia ao seu amor ou era vítima de algum mal-entendido ou de alguma calúnia. Turgut bei e as filhas se aconchegavam como gatos; as jovens encostavam a cabeça contra o peito e o ombro do pai, e os três derramavam algumas lágrimas (PAMUK, p. 277).
} 


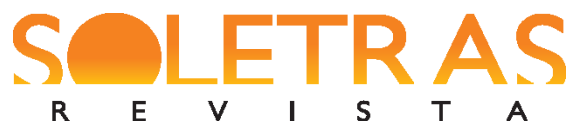

N. 36 - 2018.2 - EMILE CARDOSO ANDRADE EWERTON DE FREITAS IGNÁCIO

Quando a novela entra em questão, torna-se evidente a extraordinária força da imagem televisiva, que, a partir do momento em que se presentifica, desestrutura qualquer posição política e faz do contexto de terror algo absolutamente insignificante. Kadife - mulher cujo posicionamento ideológico é irretocável, consciente de sua importância política como defensora do uso do manto - abraça-se ao pai e chora emocionada ao acompanhar o melodrama de Marianna. Ka, por sua vez, acompanha a novela ao lado de seus torturadores, que, depois de espancarem-no, sintonizam a TV no canal em que passa a novela e acompanham a trama atenciosamente: "Uma nova onda de culpa o invadiu, enquanto ele assistia, em silêncio, com seus sequestradores, à novela Marianna, refletindo que Turgut bei e suas filhas àquela hora estavam no hotel assistindo ao mesmo programa" (PAMUK, 2006, p. 404).

O golpe político acaba da mesma forma que começou. Kadife, a amante de Azul, é levada a tirar seu manto em público - novamente num espetáculo de teatro - e acaba matando Sunay a tiros, sem saber que a arma que empunha está carregada: "O público esperava que Sunay se pusesse a fazer um longo monólogo de agonizante; em vez disso, Kadife avançou em sua direção e atirou uma, duas, quatro vezes em rápida sucessão. A cada disparo, o corpo de Sunay tremia e erguia-se num movimento brusco, caindo em seguida no chão, parecendo cada vez mais pesado." (PAMUK, 2006, p. 457). Temos, mais uma vez, o deslocamento entre realidade e ficção que envolve toda a trama. Enganada por Sunay (que trama a própria morte), Kadife comete um crime - que a princípio seria apenas encenação - mas põe fim ao regime de terror. Note-se que o fim do golpe precisa necessariamente ter um grand finale, programado pelo seu idealizador e que ainda deixa o público indeciso quanto à veracidade da cena: "Muita gente ainda pensou que Sunay estivesse apenas interpretando. Eles esperavam que ele se sentasse a qualquer momento e fizesse uma longa arenga sobre a morte, mas o aspecto extraordinariamente real de seu rosto ensanguentado lhes tirou toda a esperança" (PAMUK, 2006, p. 458).

O vínculo que une o espetáculo ao poder político está ligado ao poder e seus usos e abusos. O exagero do poder transforma-o em um nonsense e, tanto a política quanto a mídia perdem o sentido e a razão de ser quando possuem poder além de seus limites. Baudrillard afirma que a televisão já não faz questão de ser mediadora de acontecimentos, ela faz-se seu próprio

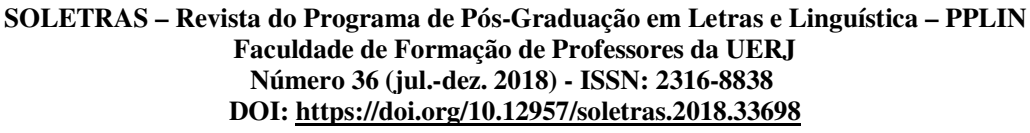




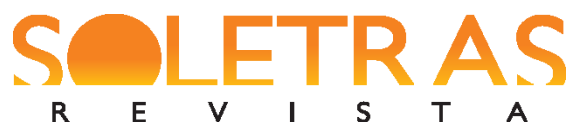

N. 36 - 2018.2 - EMILE CARDOSO ANDRADE

EWERTON DE FREITAS IGNÁCIO

acontecimento. Com o excesso de poder político ocorre o mesmo, ele acaba valendo por ele mesmo e significando nada:

Todos os poderes estão afetados pela síndrome depressiva do poder - complexo de justificação de todo e qualquer poder ao tornar-se excessivo, sem representar mais nada. É o caso do político, e hoje da mídia. A televisão passa a girar em torno de si mesma, na própria órbita, e a detalhar à vontade as suas convulsões porque não é mais capaz de encontrar sentido no exterior, ultrapassar-se enquanto meio para encontrar o seu destino: produzir o mundo como informação e dar sentido a essa informação. Por ter usado e abusado do fato através das imagens, até se tornar suspeita de produzi-lo por inteiro, está virtualmente desconectada do mundo e involui no seu próprio universo como um significante vazio de sentido, buscando desesperadamente uma ética, na falta de credibilidade, e um estatuto moral, na falta de imaginação (uma vez mais, vale o mesmo para a classe política) (BAUDRILLARD, 2005, p. 141-2).

A realidade desfragmentada pelos usos da representação e pela força da imagem, que, criada para interpretar o fato acabou por tornar-se o próprio fato, é um ponto de destaque na literatura do fim do século XX e início do XXI. Questões em torno dos limites entre o real e o ficcional, entre o factual e suas representações sempre fizeram parte do mundo literário, mas nunca com tanta força e presença. Orhan Pamuk atualiza esse debate esforçando-se em compreender de que forma a indefinição política de seu país é um resultado da desagregação do mundo contemporâneo onde já não existe ao menos lugar de definição entre o real e suas imagens produzidas pela mídia, onde o conceito de ficção se amplifica e adentra o factual, tornando qualquer tentativa de compreensão deste contexto uma tácita impossibilidade.

\section{Referências}

BAUDRILLARD, Jean. Simulacros e simulações. Lisboa: Relógio D’água, 1981.

Tela Total: mito-ironias do virtual e da imagem. Porto Alegre: Sulina, 2005.

BENJAMIM, Walter. A obra de arte na era de sua reprodutibilidade técnica. In: Magia e técnica, arte e política: ensaios sobre literatura e história da cultura. São Paulo: Brasiliense, 1994.

DEBORD, Guy. A sociedade do espetáculo. Rio de Janeiro: Contraponto, 1997.

SOLETRAS - Revista do Programa de Pós-Graduação em Letras e Linguística - PPLIN

Faculdade de Formação de Professores da UERJ

Número 36 (jul.-dez. 2018) - ISSN: 2316-8838

DOI: https://doi.org/10.12957/soletras.2018.33698 


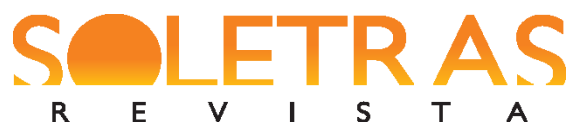

N. 36 - 2018.2 - EMILE CARDOSO ANDRADE

EWERTON DE FREITAS IGNÁCIO

GUATELLI, Igor. Arquitetura dos entre-lugares. São Paulo: Editora Senac, 2012.

LIMA, Luiz Costa. Trilogia do controle. Rio de Janeiro: Topbooks, 2007.

PAMUK, Orhan. Neve. São Paulo: Companhia das letras, 2006.

SAID, Edward W. Reflexões sobre o exílio e outros ensaios. São Paulo: Companhia das letras, 2003.

TABUCCHI, Antônio. El hilo del desasosiego. Del premio literario Casa de las Américas, Havana, Casa de las Américas, Enero-Marzo 2002.

\title{
A literature of disassembly: interculturalities and policy in Snow by Orhan Pamuk
}

\begin{abstract}
The literature of the XXI century can be defined as a production that is concerned with the intercultural experience of the subject in the globalization era in face of media convergence times. In this sense, stemming for the malaise felt due to the inter-place in which contemporary subjects transit, authors seek to approach discussions oriented to the meaning of what can still be thought about politics and intercultural aspects that permeate our world. Under this bias, we are interested in investigating the build-up of the narrative Neve - Snow -, a novel by Orhan Pamuk, published in Brazil in 2006, weaving relations between notions of fiction and reality, and how these instances are mediated by television and theater as they foster problematizations in these intercultural, political and religious times.
\end{abstract}

Keywords: Interculturality. Politics. Snow. Orhan Pamuk.

Enviado em: 15 de abril de 2018.

Aceito em: 30 de julho de 2018. 